\title{
Pyrolysis oil combustion in the CI engine
}

Pyrolysis oil obtained from thermal biomass processing (torrefaction and pyrolysis) was used as an additional fuel for the compression-ignition engine equipped with a classic (non-common rail) injection system. The basic fuel used to the engine was regular diesel fuel. The tests were carried out with two content of pyrolysis oil in diesel fuel as follows: 10 and $20 \%$ by volume. In addition, the combustion process was investigated in the engine operating only on pyrolysis oil. The test results were based on a comparative analysis, where the diesel fuel was used as the reference fuel. The obtained results indicate that is a real possibility of co-combustion of pyrolysis oil with diesel fuel in the CI engine. On the other hand, a decrease in engine power resulting from the lower calorific value of pyrolysis oil and a greater unrepeatability of engine consecutive work cycles were observed.

Key words: bio-oil, pyrolysis, CI engine

\section{Introduction}

Nowadays, bio-oil is known as a black/grey liquid obtained from used tires or biomass from their thermal processing called pyrolysis/gasification. As reported, used car tires are a growing problem in Poland and worldwide. About 200,000 tonnes of used tires are coming every year in Poland. A rubber waste fire is a threat to neighboring buildings and people living nearby such a place. Thermal processing is considered as the most effective technology for tires utilization. As a result of this processing, alternative fuel can be obtained, which can be utilized by internal combustion engines. Such a process has two main advantages: the most important is waste processing, its utilization and thus the reduction of the threat to the natural environment. The second advantage is the production of fuel, which can be used for various purposes, for example fuel for vehicles or as fuel for CHP sets $[1,6,10]$. However, technologies of thermal processing including torrefaction, pyrolysis and gasification are commonly used for biomass processing focusing on biochar and syngas production, respectively.

Pyrolysis is the process of biomass decomposition at temperature of $350^{\circ} \mathrm{C}-600^{\circ} \mathrm{C}$ without oxygen presence. Low pyrolysis temperature is also called torrefaction (process temperature around $350^{\circ} \mathrm{C}$ ). Under such conditions, the batch material decomposes. The following materials can be used as input material: wooden by-products from wood processing, waste from forestry, waste from the food industry (fish waste, coconut shells, corn cobs), energy crops (Virginia Mallow, Salix Viminalis), municipal waste (tires, selected fractions of municipal solid waste). Thermal processing of the substance results in: solid products, char (biocarbon, material with a high carbon content) and gas products. From the gas, after cooling it to ambient temperature, condensed hydrocarbon compounds. This liquid is called: bio-oil, pyrolysis oil, condensate. This fraction can be an alternative fuel used in internal combustion engines. The amount of gas and charcoal produced depends on the following: the input material, its fragmentation from the temperature and length of the process. In addition, the physicochemical properties of the liquid fuel resulting from the pyrolysis process are also varied, depending on the material fed to the pyrolysis process [2, 4, 9-13]. In our installation for thermal processing as a result of the torrefaction of Virginia mallow, a pyrolytic oil was obtained, the composition of which has the largest share of the following compounds:

- $\mathrm{C}_{18} \mathrm{H}_{35} \mathrm{NO}$ (9-Octadecenamide, (Z)-) $22.03 \%$

- $\mathrm{C}_{2} \mathrm{H}_{4} \mathrm{O}_{2}$ (Acetic acid) $13.54 \%$

- $\mathrm{C}_{3} \mathrm{H}_{6} \mathrm{O}_{2}$ (2-Propanone, 1-hydroxy-) $13.53 \%$

- $\mathrm{C}_{5} \mathrm{H}_{4} \mathrm{O}_{2}$ (Furfural) $11.93 \%$

- $\mathrm{C}_{4} \mathrm{H}_{8} \mathrm{O}_{3}$ (1,2-Ethanediol, monoacetate) $8.56 \%$

- $\mathrm{C}_{6} \mathrm{H}_{12} \mathrm{O}_{2}$ (2-Pentanone, 4-hydroxy-4-methyl-) 5.56\%.

At other temperatures $\left(300^{\circ} \mathrm{C}-375^{\circ} \mathrm{C}\right)$, the proportion of individual compounds changed. Nevertheless, these compounds are always the main components of the oil. Table 1 shows the percentage of gaseous, liquid and solid products from pyrolysis in exemplary installations described at papers [7-10].

Table 1. Comparison between individual fractions from pyrolysis process

\begin{tabular}{|l|c|c|c|c|}
\hline \multirow{2}{*}{$\begin{array}{l}\text { Pyrolysis/ } \\
\text { Torrefaction plant }\end{array}$} & Temperature & Char & Oil & Gas \\
\cline { 2 - 5 }$\left[{ }^{\circ} \mathrm{C}\right]$ & \multicolumn{3}{|c|}{$[\%]$} \\
\hline CSN ISO 647 [7] & 520 & 38.5 & 44.5 & 16.8 \\
\hline Pilot plant [7] & 600 & 39.2 & 51.8 & 7.9 \\
\hline Barbooti [3] & 460 & 34.1 & 53.0 & 12.9 \\
\hline Kaminsky [8] & 600 & 40 & 51 & 9.1 \\
\hline Williams [7] & 600 & 35 & 55 & 10 \\
\hline Boxioing [5] & 500 & 37.6 & 45.7 & 16.5 \\
\hline Our plant & 350 & 56.3 & 15.0 & 28.7 \\
\hline
\end{tabular}

As a result of pyrolysis/torrefaction of wastes from the wood industry or crops of Virginia Mallow, Salix viminalis, products that contain water in its structure, water is also transferred to condensate, which for this reason cannot be mixed with petroleum based fuels such as diesel fuel or gasoline. Such an alternative fuel can be used as an additive only to alcohol fuels. It is different in the case of the pyrolysis of tires that do not contain water in their structure and the condensate in the pyrolysis of rubber waste can be blended with diesel fuel and gasoline. This is shown in Figure 1, on the left there is a mixture of oil from pyrolysis of tires and diesel fuel 
and oil from pyrolysis of tires with gasoline, on the right is a heterogeneous mixture of oil from torrefaction of Virginia Mallow mixed with gasoline and diesel. The volume ratio is $80 \%$ of traditional fuel and $20 \%$ of the pyrolysis oil or oil from Virginia Mallow torrefaction [6].
1

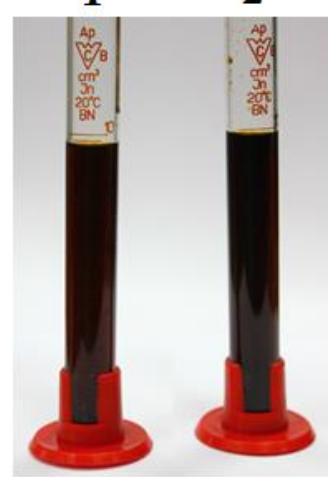

3

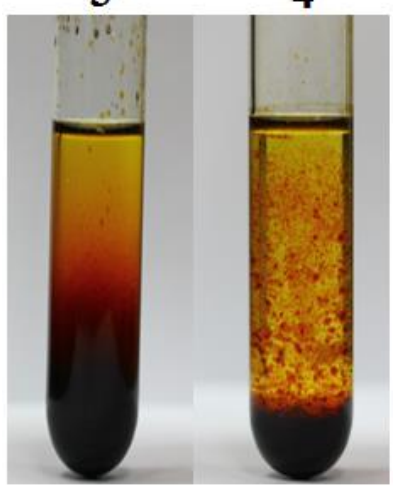

Fig. 1. Solubility oil of tyres pyrolysis in: 1 - Diesel, 2 - Gasoline, and torrefaction Virginia Mallow Oil blended with: 3 - Gasoline, 4 - Diesel

\section{Description of the research stand}

The test stand contains a 1CA90 compression-ignition piston engine by Andoria factory. Specifications of this engine are presented in Table 2. The startup of the internal combustion engine was carried out by means of a DC electric motor. The DC motor is connected in the Leonardo system with an asynchronous motor and a constant voltage generator. The rotational speed of this electric drive can be adjusted using the potentiometer. After starting the combustion engine, the DC motor was used as a brake for the engine. The in-cylinder pressure measurement was performed using a piezoelectric sensor by Kistler. In addition, the engine is equipped with an encoder to measure the current

Table 2. Data of the 1CA90 Andoria piston engine

\begin{tabular}{|c|c|}
\hline Type of engine & Four-stroke \\
\hline Fuel & Diesel \\
\hline Number of cylinders & Single \\
\hline Direct of cylinder & Vertical \\
\hline Type of valve train & $\mathrm{OHV}$ \\
\hline Number of valves & 2 \\
\hline Cylinder bore & $90 \mathrm{~mm}$ \\
\hline Piston stroke & $90 \mathrm{~mm}$ \\
\hline Engine displacement & $573 \mathrm{~cm}^{3}$ \\
\hline Compression ratio & 16.8 \\
\hline Nominal power & $6.6 \mathrm{~kW}$ \\
\hline Maximum torque & $26 \mathrm{Nm}$ \\
\hline $\begin{array}{l}\text { Specific fuel consumption at rated } \\
\text { power output }\end{array}$ & $300 \mathrm{~g} / \mathrm{kWh}$ \\
\hline Start of fuel injection & $28^{\circ}$ before TDC \\
\hline Injection pressure & 19.6-21.1 MPa \\
\hline Injector nozzle & four holes \\
\hline Intake valve timing & $\begin{array}{l}\text { Opening: } 18^{\circ} \text { before TDC } \\
\text { Closing: } 52^{\circ} \text { after BDC }\end{array}$ \\
\hline Exhaust valve timing & $\begin{array}{l}\text { Opening: } 52^{\circ} \text { before BDC } \\
\text { Closing: } 18^{\circ} \text { after TDC }\end{array}$ \\
\hline Cooling & Air cooled \\
\hline Engine speed & $1500 \mathrm{rpm}$ \\
\hline
\end{tabular}

position of the crankshaft. For data recording in real time, the SAWIR our own code was used. The measurement of toxic exhaust emissions was carried out using the AI6900 flue gas analyzer.

Figure 2 shows the diagram of the test stand with the designation of individual elements.

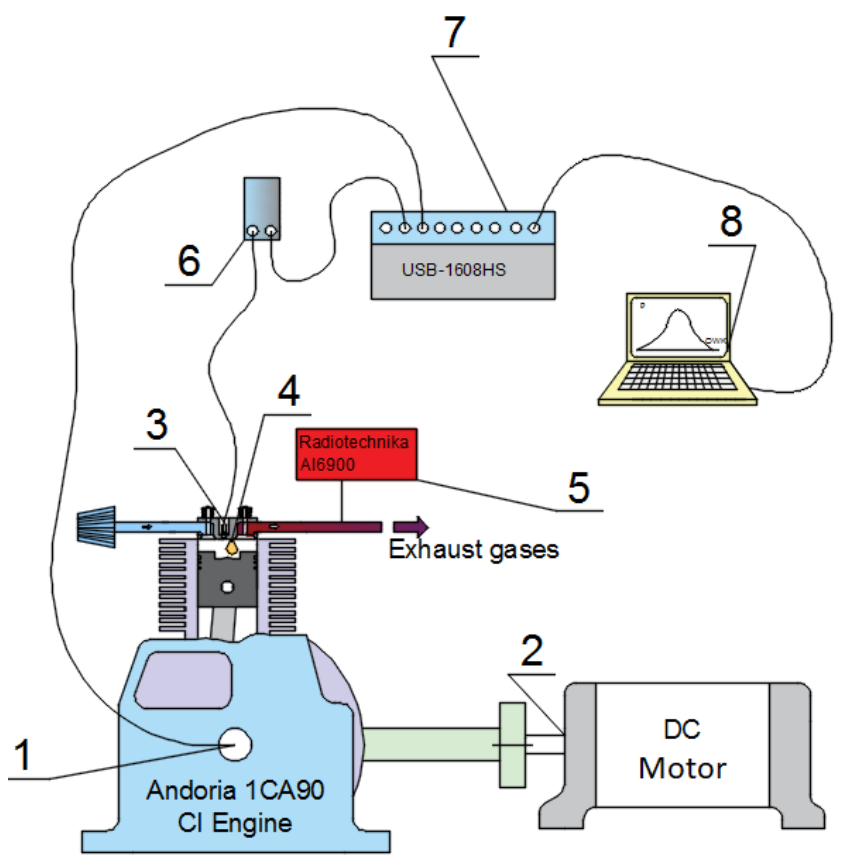

Fig. 2. Diagram of the test stand: 1 - Encoder; 2 - Ward Leonard control speed system (Load/Drive CI engine); 3 - Piezoelectric Pressure sensor Kistler 6061; 4 - Injector: Diesel/Pyrolysis Oil; 5 - Exhaust gas analyzer $\left(\mathrm{CO}_{2}, \mathrm{CO}, \mathrm{NO}_{\mathrm{x}}, \mathrm{HC}\right.$, Lambda); 6 - Charge Amplifier Kistler 5011B; 7 Data acquisition Measurement Computing USB-1608HS; 8 - PC with software SAWIR

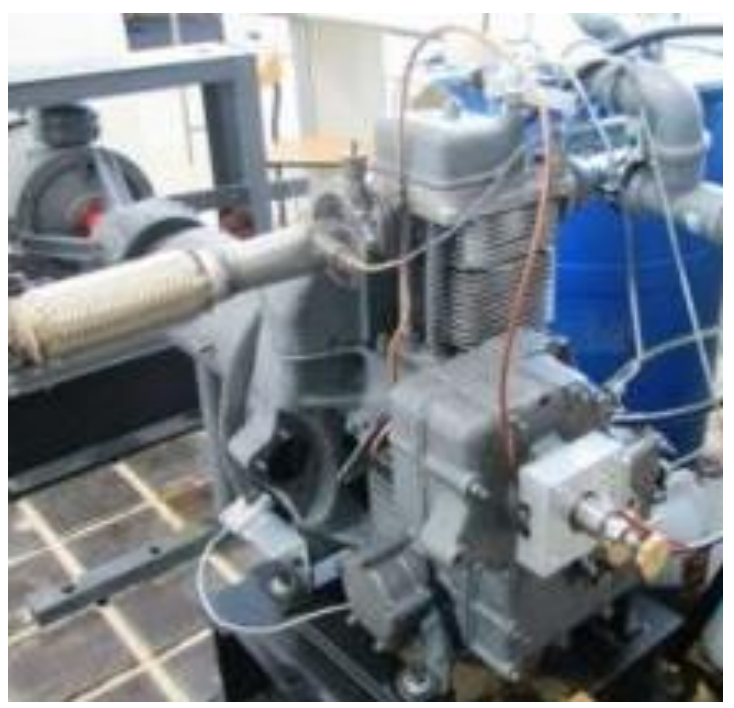

Fig. 3. Photography of the test stand

\section{Analysis of results}

As part of the tests, the pressure changes were recorded in the engine cylinder supplied with the reference fuel: diesel fuel (D) and diesel fuel mixtures with addition of pyrolysis oil (PO). Mixtures were created with the following shares by volume: 


\begin{tabular}{|c|c|} 
Table 3. Percentage share by volume of mixed fuels \\
\hline Diesel & Pyrolysis oil \\
\hline $100 \%-$ reference fuel & $0 \%$ \\
\hline $95 \%$ & $5 \%$ \\
\hline $90 \%$ & $10 \%$ \\
\hline $85 \%$ & $15 \%$ \\
\hline $80 \%$ & $20 \%$ \\
\hline $0 \%$ & $100 \%$ \\
\hline
\end{tabular}

The results of pressure changes for all fuels are presented in Figure 4. The following charts present only selected fuel mixtures.

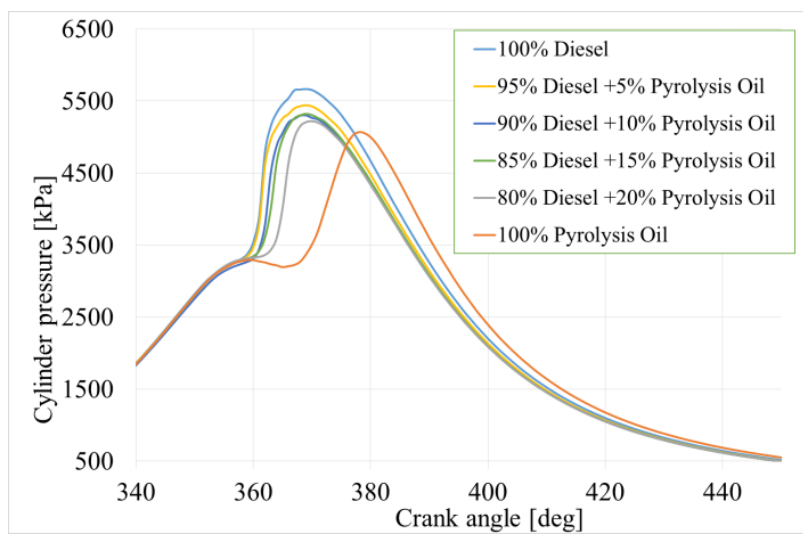

Fig. 4. Cylinder pressure vs. crank angle range $340-450^{\circ}$

From the presented Figure 4 it can be seen that with the increase of pyrolysis oil, the maximum pressure in the cylinder was slightly lower and the ignition was delayed. This is most evident for the pressure course when $100 \%$ pyrolysis oil is burned.

The pressure course can also be presented as a function of cylinder volume as shown in Fig. 5. You can easily identify the ignition delay when burning pyrolysis oil. Such a course suggests that injection of this fuel should be advanced.

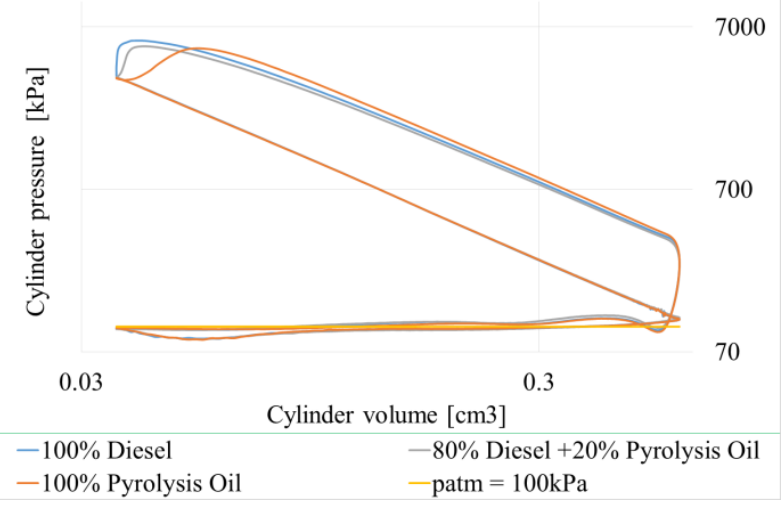

Fig. 5. Cylinder pressure vs. cylinder volume in log scale

Based on the registered pressure changes in the engine cylinder, the rate of in-cylinder pressure change was calculated and shown in Figure 6. Addition of oil from pyrolysis reduces the rate of combustion. Combustion lasts longer and is not as violent as in the case of reference fuel (diesel fuel).

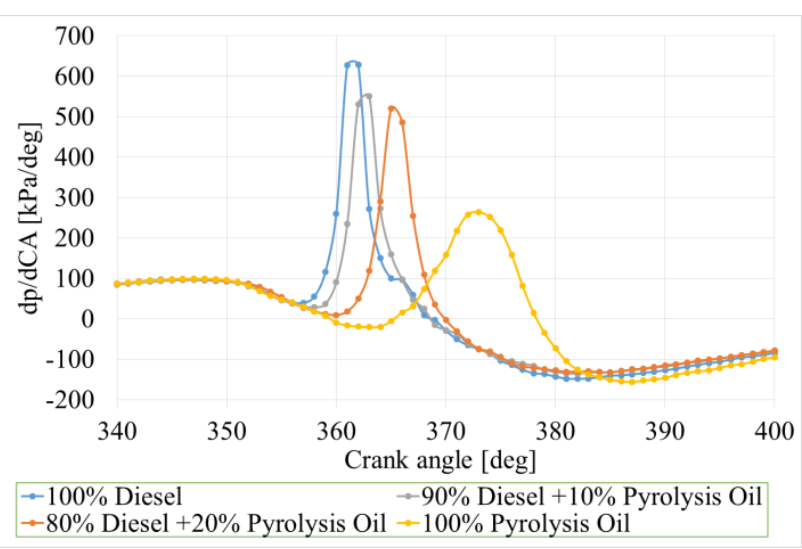

Fig. 6. Pressure rise rate vs. crank angle

One of the criteria for assessing the correct operation of an internal combustion engine is the unrepeatability of its work cycles. The indicated work was selected as the parameter determining the unrepeatability of the engine operation. In order to determine the unrepeatability of the engine operation, the following relationship was used:

$$
\operatorname{COV}_{\mathrm{Li}}=\frac{\sigma(\mathrm{Li})}{\overline{\mathrm{Ll}}}=\frac{\sqrt{\frac{1}{\mathrm{k}} \sum_{\mathrm{i}=1}^{\mathrm{k}}\left(\mathrm{Li}_{\mathrm{i}}-\overline{\mathrm{Ll}}\right)^{2}}}{\overline{\mathrm{L} l}} \cdot 100 \%
$$

where: $\sigma(\mathrm{Li})$ - standard deviation of the indicated work, $\overline{\mathrm{L}}$ - average value of indicate work from 100 cycles, $\mathrm{Li}_{\mathrm{i}}-$ indicated work of the $\mathrm{i}$-th cycle, $\mathrm{k}$ - number of analyzed cycles.

For the tested fuel, the same pyrolysis oil, the unrepeatability of the engine operation was $3.1 \%$. This is a value not much higher than calculated for the diesel engine. For a reference fuel, the unrepeatability value was $2.6 \%$.

The next Figure, Fig. 7, shows the value of the maximum pressure and angle of rotation of the crankshaft at which the maximum pressure occurred. Presented is a set of results for 3 fuels: reference fuel, i.e. diesel, only oil from pyrolysis, and a mixture of diesel and pyrolysis oil $(80 \%$ diesel $+20 \%$ pyrolysis oil).

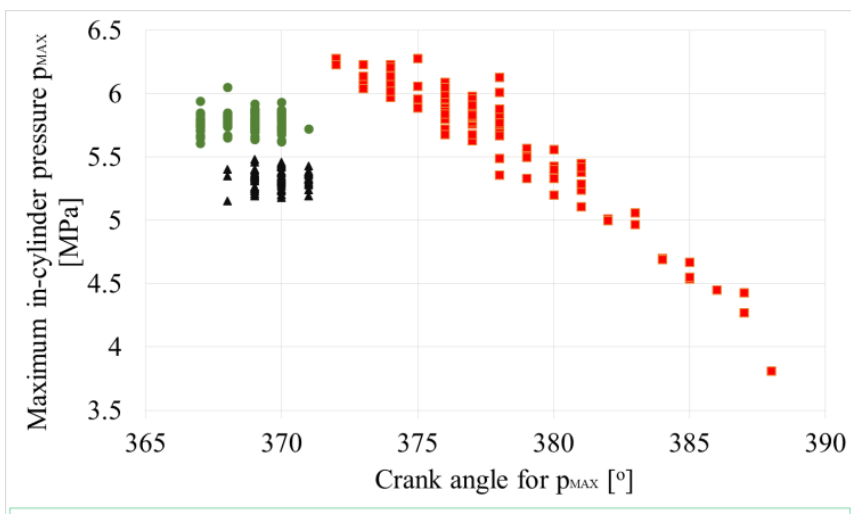

- $100 \%$ Diesel - $100 \%$ Pyrolysis Oil • $80 \%$ Diesel $+20 \%$ Pyrolysis Oil

Fig. 7. Graph showing values of maximum pressure and angle of rotation of the crankshaft for which maximum pressure was recorded for 100 engine cycles

From the graph it can be seen that for the reference fuel, the maximum pressure does not have large fluctuations and 
is always in the range of 367-371 degrees of crankshaft rotation. Addition of $20 \%$ oil from pyrolysis to fuel caused a slight delay of the pressure peak, in addition the maximum value decreased as compared to the reference fuel. In the case of engine operation on the pyrolysis oil itself, the maximum pressure has a large dispersion: from almost 4 $\mathrm{MPa}$ to over $6 \mathrm{MPa}$. In addition, the maximum pressure value occurs in a wide range of crankshaft angle (from 372 degrees of crankshaft rotation to 388 degrees of crankshaft rotation). This is a confirmation of the result of the increased unrepeatability of the engine's operation.

During the tests, emissions of toxic exhaust components were registered. The graph (Fig. 8) presents the changes in carbon monoxide emissions for various fuels from pyrolysis in fuel.

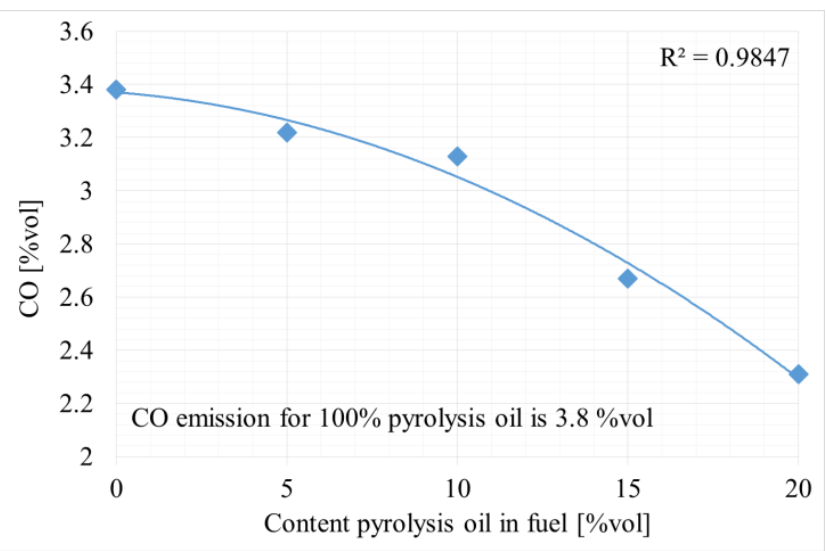

Fig. 8. CO emission versus content of pyrolysis oil in analyzed fuel

The graph shows a downward trend in $\mathrm{CO}$ emissions with an increase in the oil from pyrolysis in the range of 0 $20 \%$. However, the emission of $\mathrm{CO}$ for fuels consisting only of pyrolysis oil is higher $(3.8 \%)$ than for the reference fuel (CO emission has a value of $3.4 \%$ ).

The next chart shows the emission of $\mathrm{NO}_{\mathrm{x}}$ in the exhaust (Fig. 9). In this case, a decrease in the emission of nitrogen oxides with the increase of oil from pyrolysis in the fuel was also observed. This may be due to a milder combustion process, during which temperatures are not reached as high as in the case of diesel engine operation. For an engine running only on pyrolysis oil, the $\mathrm{NO}_{\mathrm{x}}$ emission is $259 \mathrm{ppm}$.

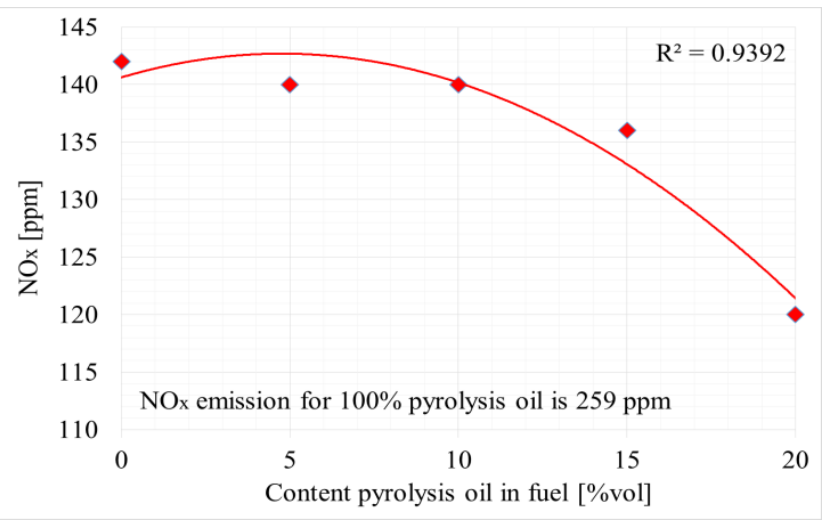

Fig. 9. $\mathrm{NO}_{\mathrm{x}}$ emission versus content of pyrolysis oil in analyzed fuel
The last measured exhaust component are hydrocarbons, shown in Figure 10. In this case, it was not possible to determine an unambiguous trend, hence only measuring points were marked on the graph. The test was repeated twice, hence the data is the aceraged data from 3 measurements. Having this on mind, the $\mathrm{HC}$ emission for $10 \%$ pyrolysis oil seems to be credible. The $\mathrm{HC}$ emission for pure pyrolysis oil was $181 \mathrm{ppm}$ and was similar to other tests except $10 \%$ pyros oil.

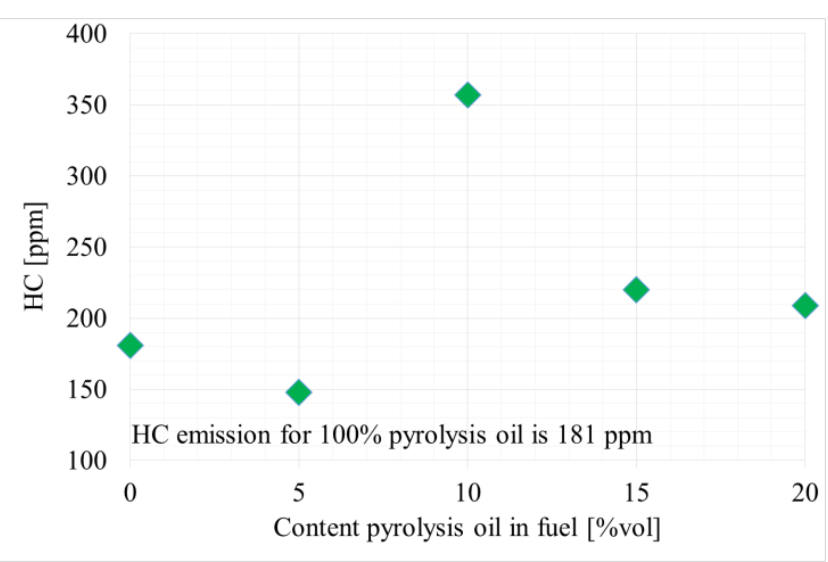

Fig. 10. HC emission versus content of pyrolysis oil in analyzed fuel

During the research, an unfavorable phenomenon of precipitation in the mixture was observed. The precipitate formed after mixing diesel oil and pyrolysis oil. The sediment on the bottom appeared after several minutes from mixing (Fig. 11). No more was formed after filtering the sediment mixture. Before mixing, the two liquids were filtered and did not contain impurities. The precipitate is a jelly-like substance that unfortunately causes the fuel filter built into the fuel system to become clogged.

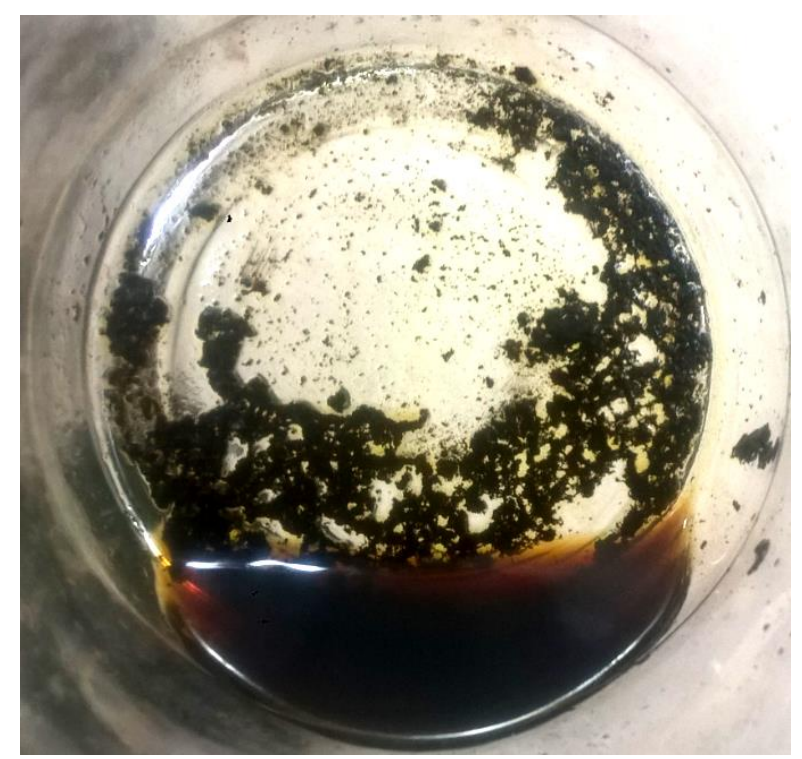

Fig. 11. Sludge from a mixture of diesel and oil from tire pyrolysis

\section{Conclusion}

Pyrolysis oil can be formed from the thermal processing of various substances: wood industry waste, special crops, waste from the food industry, used car tires, etc. In the 
world and in Poland, there are many installations that work and offer products from the pyrolysis process. Pyrolysis reactors have different constructions and operate at different temperatures. A change in the temperature of the pyrolysis process results in a change in the share of individual product fractions produced during pyrolysis.

The pyrolysis oil has different properties depending on the batch material that is used in the thermal processing. The pyrolysis oil, which is produced from substances of vegetable origin, contains water. This component prevents the mixing of such oil with conventional fuels: diesel oil and gasoline. There is almost immediate stratification after mixing these two substances. This is the case for the gasoline / diesel fuel mixture with the Virginia Mallow pyrolysis oil. It is different in the case of pyrolysis of rubber waste. The pyrolysis oil does not contain water and mixes well with gasoline and diesel.

After a while, after mixing oil from pyrolysis and diesel, a gelatinous substance precipitates at the bottom of the container, therefore the mixture must be filtered before being fed to the fuel system. Otherwise, the fuel filter will clog and the engine will stop working. This is a troublesome problem, hence an attempt was made to start the engine only on pyrolysis oil. The trial was positive. The engine was able to run on pyrolysis oil and was constantly working during measurements.

Based on the recorded data, it can be seen that the engine working on the pyrolysis oil itself has a more unrepeatable operation. The maximum pressure has a large dispersion. In addition, the maximum pressure occurs for a wide range of crank angle rotation. This may be due to the precipitation of a jelly-like substance in the fuel system. The advantage of the engine's work on pyrolysis oil is the higher average value of the indicated work. In addition, combustion occurs less rapidly.

In order to improve the combustion efficiency of engine pyrolysis oil, it would be necessary to inject fuel earlier than conventional fuel, since the pyrolysis oil has a delayed ignition. On average, the maximum pressure for diesel oil is for the crankshaft position 9 degrees after TDC, and for pyrolysis oil the medium of maximum pressure is $18 \mathrm{de}$ grees after TDC.

The addition of pyrolysis oil to the reference fuel causes reduces the toxic components of the exhaust gas. For $\mathrm{CO}$, the decrease is $31.5 \%$ with the addition of $20 \%$ of the volume of pyrolysis oil to the reference fuel. In the case of $\mathrm{NO}_{\mathrm{x}}$, the decrease is $15.5 \%$ with a share of $20 \%$ by volume of pyrolysis oil. Hydrocarbons has similar values for the reference fuel and mixture. In the case of engine operation on the pyrolysis oil alone, the emissions is higher than for diesel.

The injection timing was not changed in the tests presented, because it was the first step in investigation focusing on combustion progress comparison where several different fuels were applied. Therefore, injection timing optimization was not done in these tests. It is expected that toxic $\mathrm{CO}$ and $\mathrm{NO}_{\mathrm{x}}$ emissions are changed with changing fuel's LHV. But, the emissions results were used only to confirm impact of combustion duration (based on HRR plots) on maximum combustion pressure-temperature, so $\mathrm{CO}$ and $\mathrm{NO}_{\mathrm{x}}$ emissions, respectively.

\section{Acknowledgments}

The present research was conducted in the frame of the project No. BIOSTRATEG1/270745/2/NCBR/2015, entitled: "Dietary, Power and Economic Potential of Sida Hermaphrodita Cultivation on Fallow Land" supported by the Polish National Centre for Research and Development.

Section 3 was partially done under the project which has received funding from the European Union's Horizon 2020 research and innovation programme under grant agreement No 691232 - Knocky - H2020-MSCA-RISE-2015/ H2020MSCA-RISE-2015 and the research was additionally cofinanced by Polish Ministry of Science within the frame of science support funds for international co-funded projects in 2016-2019.

\section{Nomenclature}

BDC bottom dead center

CA crank angle

CHP combined heat and power

CI compression ignition

$\mathrm{CO}$ carbon monoxide

$\mathrm{COV}$ coefficient of variation

D diesel

DC direct current

DI direct injection
HC hydrocarbons

IC internal combustion

IMEP indicated mean effective pressure

$\mathrm{Li}$ indicate work

NOx nitrogen oxides

$\mathrm{OHV}$ overhead valves

PO pyrolysis oil

TDC top dead center

\section{Bibliography}

[1] AMBROSEWICZ-WALACIK, M., DANIELEWICZ, T. Pyrolytic oil and petroleum fractions obtained by pyrolysis of vehicle tires as an energy sources for compression-ignition engines. Combustion Engines. 2015, 162(3), 952-957.

[2] AMBROSEWICZ-WALACIK, M., TAŃSKA, M., WALACIK, M., NITKIEWICZ, S. Production of fuel blends from diesel oil and waste products. Combustion
Engines. 2017, 171(4), 255-258. DOI: 10.19206/CE2017-443

[3] BARBOOTI, M.M., MOHAMED, T.J., HUSSAIN, A.A., ABAS, F.O. Optimization of pyrolysis conditions of scrap tires under inert gas atmosphere. Journal of Analytical and Applied Pyrolysis. 2004, 72, 165-170. 
[4] BOGARRA-MACIAS, M., DOUSTDAR, O., FAYAD, M.A. et al. Performance of a drop-in biofuel emulsion on a single-cylinder research diesel engine. Combustion Engines. 2016, 166(3), 9-16. DOI: 10.19206/CE-2016-324

[5] BOXIONG, S., CHUNFEI, W., LIANG, C. et al. Pyrolysis of waste tyres: the influence of USY catalys/tyre ratio on products. Journal of Analytical and Applied Pyrolysis. 2006, 78, 243-249.

[6] CHWIST, M., SZWAJA, S., GRAB-ROGALIŃSKI, K., PYRC, M. Bio-oil blended butanol as a fuel to the spark ignition internal combustion reciprocating engine. Combustion Engines. 2017, 169(2), 93-96. DOI: 10.19206/CE-2017-216

[7] ČÍŽKOVÁ, A., JUCHELKOVÁ, D. Comparison of yield of tires pyrolysis in laboratory and pilot scales. GeoScience Engineering. 2009, LV, 4, 60-65.

[8] KAMINSKY, W., MENNERICH, C. Pyrolysis of synthetic rubber in a fluised-bed reactor to yield 1,3butadiene,styrene and carbon black. Journal of Analytical and Applied Pyrolysis. 2001, 58-59, 803-811.

Mariusz Chwist, MEng. - Faculty of Mechanical Engineering and Computer Science, Czestochowa University of Technology.

e-mail: chwist@imc.pcz.pl
[9] KLINGER, J., BAR-ZIV, E., SHONNARD, D. Unified kinetic model for torrefaction-pyrolysis. Fuel Processing Technology. 2015, 138, 175-183.

[10] KUMARAVEL, S.T., MURUGESAN, A., KUMARAVEL, A. Tyre pyrolysis oil as an alternative fuel for diesel engines - a review. Renewable and Sustainable Energy Reviews. 2016, 60, 1678-1685.

[11] RYBAK, A., HUNICZ, J., KRZACZEK, P. et al. Effect of different biofuels on common rail injector flow rate. Combustion Engines. 2017, 171(4), 39-43. DOI: 10.19206/CE-2017-407

[12] UMEKI, E.R., de OLIVEIRA, C.F., TORRES, R.B., dos SANTOS, R.G. Physico-chemistry properties of fuel blends composed of diesel and tire pyrolysis oil. Fuel. 2016, 185, 236-242.

[13] WONGKHORSUB, C., CHINDAPRASERT, N., PEANPRASIT, S. Engine performance and economic impact study of gasoline-like tyre pyrolysis oil in Thailand. Advances in Environmental Sciences, Development and Chemistry. 2014, 340-344. ISBN: 978-1-61804239-2.
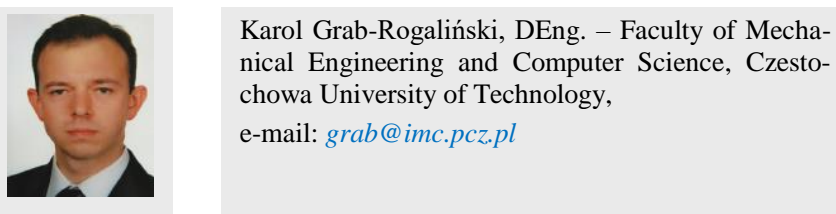